\title{
Perbandingan Antara Kompres Hangat dan Akupressure untuk Menurunkan Nyeri Punggung Bawah Ibu Hamil Trimester III
}

\author{
Morista Citra Pratama ${ }^{1}$, Kuswati ${ }^{2}$, Lutfiana Puspita Sari ${ }^{3}$ \\ ${ }^{1,2,3}$ Jurusan Kebidanan, Poltekkes Kemenkes Surakarta \\ *Email: bidanlutfiana@gmail.com
}

\begin{abstract}
Background: Lower back pain is discomfort under costa and top of the gluteal inferior that experienced by $70 \%$ pregnant women in Indonesia. Warm compresses increase oxygenation and acupressure provides balance to the body. Aim this study is to analyze the effect of warm compresses and acupressure on lower back pain in third trimester pregnant women. Methods: This research uses pre-experimental design with pretest-posttest group design. It is used Purposive Sampling with 30 third trimester of pregnant woman as respondent. Bivariate analysis use the shapiro wilk by comparing pre and posttests using paired test. Meanwhile, to compare the effect of warm compresses and acupressure by using independent $t$ test.Results: Bivariate analysis showed that $p$ value of warm compresses is 0.00 with the difference of mean is 2,3. While, p value of acupressure is 0.00, with the difference of mean is 1,2. Conclusion: There is an effect of warm compresses and acupressure on lower back pain in the third trisemeter of pregnant women.
\end{abstract}

Keywords: acupressure, lower back pain, warm compress.

\section{PENDAHULUAN}

Kehamilan merupakan salah satu kondisi dimana seorang perempuan sedang mengandung dan mengembangkan fetus didalam rahimnya selama sembilan bulan (Prawirohardjo, 2012). Menurut Kemenkes RI (2010), perubahan sistem musculoskeletal pada ibu hamil akan menyebabkan ibu sering merasakan nyeri punggung bawah. Nyeri punggung bawah merupakan ketidaknyamanan yang terjadi dibawah costa dan diatas bagian inferior gluteal (Prabowo, 2012). Nyeri punggung akan meningkat seiring dengan meningkatnya usia kehamilan (Ummah, 2017).

Nyeri punggung akan menghambat aktivitas ibu hamil. Ibu hamil dengan nyeri punggung akan kesulitan berjalan ketika nyeri sudah menjalar ke pelvic. Apabila tidak ditangani dengan baik, dapat menyebabkan nyeri punggung kronis yang akan lebih sulit untuk diobati atau disembuhkan (Rasyid \& Igirisa, 2019). Menurut Yuspina (2018) prevalensi nyeri punggung ibu hamil trimester III secara global berdasarkan survey yang dilakukan di Inggris dan Skandinavia, 50\% ibu hamil trimester III menderita nyeri punggung yang signifikan. Sedangkan di Indonesia sendiri, dilaporkan bahwa $70 \%$ ibu hamil mengalami nyeri punggung pada trimester III (Permatasari, 2019). Baik ibu primigravida maupun multigravida yang mengalami nyeri punggung yang berdampak pada ativitas sehari-hari mereka (Ummah, 2012). 10\% dari ibu hamil dengan nyeri punggung melaporkan bahwa mereka tidak dapat berkerja. Sepertiga dari mereka menderita nyeri punggung hebat yang menyebabkan penurunan kualitas hidup (Katonis, 2011).

Perubahan sistem muskuloskeletal yang juga dialami di trimester tiga kehamilan yaitu memendeknya otot abdomen seiring membesarnya rahim. Sejalan dengan hal tersebut, maka pusat gravitasi tubuh juga semakin bergeser condong kedepan sehingga terjadi 
ketidakseimbangan otot disekitar panggul dan punggung bawah. Ketegangan ligament dan keadaan lordosis pada lumbal ini yang menyebabkan rasa sakit pada punggung bawah ibu (Purnamasari, 2019).

Penatalaksanaan nyeri punggung dapat digolongkan dalam dua acara yaitu farmakologis dan non farmakologis (Setyowati, 2018). Penatalaksanaan nonfarmakologis meliputi manual terapi seperti pijat dan latihan mobilisasi, akupuntur, relaksasi, terapi air hangat dan air dingin (Setyowati, 2018). Penggunaan intervensi non farmakologis dapat dijadikan alternatif terapi untuk megurangi nyeri punggung karena tidak memiliki efek samping (Movahedi, 2017).

Kompres hangat adalah sebuah metode menggunakan panas untuk menekan daerah nyeri untuk menimbulkan efek fisiologis. Kompres hangat merupakan tindakan kompres dengan air hangat bersuhu $37-40^{\circ} \mathrm{C}$ ke permukaan tubuh. Kompres hangat dapat dilakukan menggunakan handuk yang dicelupkan ke air hangat lalu diperas ataupun dengan botol yang diisi air hangat. Hal ini bertujuan untuk mengurangi rasa nyeri dan mencegah terjadinya spasme otot sehingga memberikan rasa nyaman pada ibu hamil trimester III (Andreine, 2016).

Terapi kompres hangat akan menyalurkan sinyal ke hypothalamus melalui spinal cord yang menyebabkan pembuluh darah perifer melebar (Wulandari, 2016). Adanya vasodilatasi dapat menyingkirkan produk-produk inflamasi, seperti bradikin, histamin, dan prostaglandin (Zahroh \& Faiza, 2018). Akupresur merupakan terapi yang dilakukan dengan memberikan stimulasi atau pijatan pada titik-titik tertentu atau acupoint pada tubuh. Stimulasi pada acupoint tubuh mempengaruhi aliran bioenergi tubuh (qi) menjadi teratur sehingga mengembalikan system keseimbangan tubuh (Setyowati, 2018). Stimulasi pada acupoint tubuh memengaruhi aliran bioenergi tubuh (qi) menjadi teratur sehingga mengembalikan sistem keseimbangan tubuh (Setyowati, 2018).

Akupresur ini diketahui merangsang serat Ad yang masuk ke bagian dorsalis medula spinalis. Hal ini menimbulkan inhibisi segmental dari rangsangan nyeri yang dihantarkan oleh serat $\mathrm{C}$ yang berjalan lebih lambat, dan melalui koneksi di otak bagian tengah, menyebabkan inhibisi rangsangan nyeri pada serat $\mathrm{C}$ di bagian lain dari medula spinalis. Hal ini dapat menerangkan mengapa pijatan akupresur pada titik tertentu dapat menghilangkan sensasi nyeri di bagian lain dari tubuh.

Penelitian terkait dengan pengaruh kompres hangat maupun akupresur dalam pengurangan nyeri punggung ibu hamil sudah banyak dilakukan. Seperti penelitian yang dilakukan Yuspina (2018) yang berjudul "Pengaruh Kompres Hangat dan Kompres Dingin terhadap Nyeri Tulang Belakang Ibu Hamil Trimester III" yang menunjukkan ada perbedaan tingkat nyeri sebelum dan setelah dilakukan kompres air hangat. Penelitian mengenai akupresur juga telah dilakukan oleh Permatasari (2018) dengan judul Efektifitas Tehnik Akupresur Pada Titik BL23 , GV 3 , GV 4 terhadap Penurunan Nyeri Punggung Bawah Pada Kehamilan Trimester III di Puskesmas Jelakombo Jombang. Keterbaruan yang ada pada penelitian ini yaitu membandingkan pengaruh kompres hangat dan akupresur dalam mengurangi nyeri punggung bawah ibu hamil trimester III. Akupresur 
dilakukan pada 4 titik yaitu BL23, GV3, GV4 dan KI3. Tujuan studi ini untuk menganalisis pengaruh kompres hangat dan akupresur terhadap nyeri punggung bawah ibu hamil trimester III.

\section{METODE PENELITIAN}

Penelitian ini termasuk jenis penelitian pre-experimental dengan metode penelitian pre-test post -test group design. Populasi pada penelitian ini adalah seluruh ibu hamil trimester III di wilayah kerja Puskesmas Ngemplak yang mengalami nyeri punggung bawah pada bulan Februari - Maret 2020. Populasinya berjumlah 38 subjek penelitian. Teknik pengambilan sampel menggunakan purposive sampling dengan kriteria inklusi dan eksklusi. Jumlah sampel penelitian sebanyak 30 responden dengan klasifikasi 15 responden pada intervensi kompres hangat dan 15 responden pada intervensi akupresur.

Pengambilan data diawali dengan penentuan kriteria, informed consent, pengukuran tingkat nyeri, intervensi kompres hangat maupun akupresur. Pada titik BL23, GV3, GV4 dan KI3, setelah itu dilakukan pengukuran tingkat nyeri.
Kompres dengan handuk hangat dilakukan selama 20 menit pada punggung bawah ibu. Sedangkan akupresur dilakukan selama 3 menit pada masing-masing titik, sehingga total dilakukan selama 12 menit.

Analisa bivariate menggunakan uji Shapiro wilk dengan membandingkan pre dan post test menggunakan uji paired $t$ test. Sedangkan untuk membandingkan pengaruh kompres hangat dan akupressur menggunakan uji independent $t$ test. Instrumen yang digunakan untuk mengukur nyeri yaitu Visual Analog Scale (VAS) yang merupakan suatu alat seperti penggaris dengan modifikasi skala 1-10 yang mewakili intensitas nyeri digunakan dengan cara responden menggeser alat tersebut sesuai dengan tingkat nyeri yang dirasakan.

\section{HASIL PENELITIAN}

Karakteristik responden yang diberikan intervensi kompres hangat maupun akupresur di wilayah kerja Puskesmas Ngemplak, tersaji sebagai berikut :

Tabel 1. Distribusi Frekuensi Karakteristik Responden

\begin{tabular}{lrrrc}
\hline \multirow{2}{*}{ Kelompok } & \multicolumn{2}{c}{ Kelompok } & \multicolumn{2}{c}{$\begin{array}{c}\text { Kelompok } \\
\text { Akupresur }\end{array}$} \\
\cline { 2 - 5 } & \multicolumn{1}{c}{ Kompres Hangat } & f & f & \% \\
\hline Umur & 14 & 93.3 & 10 & 66.7 \\
20-35 tahun & 1 & 6.7 & 5 & 33.3 \\
$>$ 35 tahun & & & & \\
Pendidikan & 1 & 6.7 & 2 & 13.3 \\
Dasar & 14 & 93.3 & 12 & 80 \\
Menengah & 0 & 0 & 1 & 6.7 \\
Tinggi & & & & 66.7 \\
Pekerjaan & 12 & 80 & 10 & 26.7 \\
IRT & 1 & 6.7 & 4 & \\
Swasta & & & & \\
\hline
\end{tabular}




\begin{tabular}{lrrrr}
\hline Wiraswasta & 2 & 13.3 & 1 & 6.7 \\
Paritas & & & & \\
Primipara & 5 & 33.3 & 5 & 33.3 \\
Multipara & 10 & 66.7 & 10 & 66.7 \\
\hline
\end{tabular}

Berdasarkan tabel 1 di atas dapat diketahui pada kategori umur kelompok kompres hangat mayoritas ibu hamil berumur 20-35 tahun sebanyak 14 ibu hamil (93.3\%), sedangkan pada kelompok Akupressur mayoritas ibu hamil berumur 20-35 tahun sebanyak 10 ibu hamil (66.7\%). Pendidikan pada kedua kelompok mayoritas ibu hamil dengan pendidikan menengah. Kelompok kompres hangat sebanyak 14 ibu hamil (93,3\%), sedangkan pada kelompok Akupressur sebanyak 12 ibu hamil (80\%).
Pekerjaan pada kedua kelompok mayoritas ibu hamil dengan pekerjaan Ibu Rumah Tangga. Kelompok kompres hangat sebanyak $12 \mathrm{ibu}$ hamil (80\%), sedangkan pada kelompok Akupressur sebanyak $10 \mathrm{ibu}$ hamil (66.7\%). Paritas kelompok kompres hangat mayoritas ibu hamil dengan paritas ibu multipara sebanyak 10 ibu hamil (66.7\%), sedangkan pada kelompok Akupressur ibu hamil dengan paritas ibu multipara sama sebanyak $10 \mathrm{ibu}$ hamil (66.7\%).

Tabel 2. Distribusi Frekuensi Responden Berdasarkan Nilai Nyeri Sebelum dan Sesudah Intervensi dengan Kompres Hangat

\begin{tabular}{lllcccc}
\hline Nyeri & N & Mean & $\boldsymbol{\delta}$ & Min & Max & SD \\
\hline Pre & 15 & 4.580 & 2.340 & 2.2 & 7.1 & 1.420 \\
Post & 15 & 2.240 & & 1 & 4.6 & 1.786 \\
\hline
\end{tabular}

Berdasarkan data tabel 2 dapat dianalisis bahwa distribusi frekuensi sebelum dilakukan intervensi kompres hangat memiliki rata-rata 4.580 .
Sedangkan setelah dilakukan kompres hangat rata-rata nyeri punggung bawah pada ibu yaitu 2.240.

Tabel 3. Distribusi Frekuensi Responden Berdasarkan Nilai Nyeri Sebelum dan Sesudah Intervensi Akupressure

\begin{tabular}{ccccccc}
\hline Nyeri & N & Mean & $\boldsymbol{\delta}$ & Min & Max & SD \\
\hline Pre & 15 & 3.568 & 1.196 & 1.7 & 7.7 & 2.010 \\
Post & 15 & 2.372 & & 1 & 5.8 & 1.774 \\
\hline
\end{tabular}

Berdasarkan data tabel 3 dapat dianalisis bahwa distribusi frekuensi sebelum dilakukan intervensi akupresur memiliki rata-rata nyeri 3.568. Sedangkan setelah dilakukan akupresur rata-rata nyeri pada ibu yaitu 2.372 . 
Tabel 4. Distribusi Frekuensi Responden Berdasarkan Selisih Nilai Nyeri Sebelum dan Sesudah Intervensi Kompres Hangat dan Akupresur

\begin{tabular}{lcccccc}
\hline Nyeri & N & Mean & $\boldsymbol{\delta}$ & Min & Max & SD \\
\hline Kompres Hangat & 15 & 2.266 & 1.066 & 1 & 3.1 & 0.956 \\
Akupresur & 15 & 1.200 & & 0.4 & 2.3 & 0.546 \\
\hline
\end{tabular}

Berdasarkan data tabel 4 dapat dianalisis bahwa selisih nilai nyeri punggung bawah ibu hamil trimester III dengan intervensi kompres hangat memiliki rata-rata nyeri 2.266. Sedangkan selisih nilai nyeri punggung bawah ibu hamil trimester III dengan intervensi akupresur memiliki rata-rata 1.200 . Uji normalitas data pada penelitian ini adalah uji shapiro wilk dengan nilai kemaknaan (p) > 0,05. Uji Shapiro Wilk digunakan karena jumlah sampel yang digunakan dalam penelitian ini adalah 30 responden.

Tabel 5. Tes Statistik Perbedaan Intensitas Nyeri Punggung Sebelum dan Sesudah diberikan Kompres Hangat

\begin{tabular}{lcccc}
\hline Kompres Hangat & Tingkat Nyeri & $\boldsymbol{\delta}$ & $\boldsymbol{t}$ test & p value \\
\hline Pre Test & 4.580 & 2.340 & 9.494 & 0.000 \\
Post Test & 2.240 & & & \\
\hline
\end{tabular}

Berdasarkan hasil uji statistik ada pengaruh kompres hangat terhadap dengan menggunanakan paired $t$ test nyeri punggung bawah ibu hamil trimester diperoleh $\mathrm{t}$ hitung 9.4 dengan $p$ value III di Wilayah Kerja Puskesmas 0.000 dan selisih mean 2.340 yang berarti Ngemplak, Boyolali.

Tabel 6. Tes Statistik Perbedaan Intensitas Nyeri Punggung Sebelum dan Sesudah diberikan Akupressure

\begin{tabular}{lcccc}
\hline Akupresur & Tingkat Nyeri & $\boldsymbol{\delta}$ & $\boldsymbol{t}$ test & $\boldsymbol{p}$ value \\
\hline Pre Test & 3.568 & 1.196 & 8.506 & 0.000 \\
Post Test & 2.372 & & & \\
\hline
\end{tabular}

Berdasarkan hasil uji statistik ada pengaruh akupresur terhadap nyeri dengan menggunanakan paired $t$ test punggung bawah ibu hamil trimester III di diperoleh $\mathrm{t}$ hitung 8.506 dengan $p$ value Wilayah Kerja Puskesmas Ngemplak, 0.000 dan selisih mean 1.196 yang berarti Boyolali.

Tabel 7. Tes Statistik Perbedaan Pemberian Kompres Hangat dan Akupressure Terhadap Nyeri Punggung pada Ibu Hamil Trimester III

\begin{tabular}{lcccc}
\hline Intervensi & Tingkat Nyeri & $\boldsymbol{\delta}$ & $\boldsymbol{t}$ test & $\boldsymbol{p}$ value \\
\hline Kompres Hangat & 2,266 & 1,066 & 3,750 & 0,001 \\
Akupresur & 1,200 & & & \\
\hline
\end{tabular}


Berdasarkan tabel 7 hasil uji statistik dengan menggunakan independent $t$ test diperoleh t hitung 3.750 dengan $p$ value 0,001 . Intervensi kompres hangat memiliki rata-rata selisih nyeri 2,266, sedangkan intervensi akupresur memiliki rata-rata selisih 1,200 . Selisih mean pada kedua intervensi tersebut yaitu 1,066. Hal ini menunjukkan bahwa ada perbedaan yang signifikan antara pemberian kompres hangat dan akupressure terhadap penurunan nyeri punggung pada ibu hamil trimester III.

\section{PEMBAHASAN}

Dari hasil penelitian ini dapat diketahui bahwa terdapat perbedaan yang bermakna dan signifikan untuk nyeri punggung bawah responden antara intervensi kompres hangat dan akupresur. Kompres hangat lebih signifikan dalam menurunkan nyeri punggung bawah pada ibu hamil trimester III. Penelitian Maryani (2018) yang dilaporkan bahwa setelah dilakukan pada 20 responden dengan menggunakan lembar NRS, hasil analisis bivariat menunjukan terdapat perbedaan yang signifikan sebelum dan sesudah diberikan kompres hangat. Ada pengaruh signifikan kompres hangat terhadap penurunan nyeri punggung bawah ibu hamil trimester III.

Kompres hangat merupakan tindakan kompres dengan air hangat bersuhu $37-40^{\circ} \mathrm{C}$ ke permukaan tubuh. Kompres hangat dapat dilakukan menggunakan handuk yang dicelupkan ke air hangat lalu diperas ataupun dengan botol yang diisi air hangat. Hal ini bertujuan untuk mengurangi rasa nyeri dan mencegah terjadinya spasme otot sehingga memberikan rasa nyaman pada ibu hamil trimester III (Andreine, 2016). Kompres hangat dapat meredakan nyeri dengan merileksasi otot, memberi efek sedatif dan dengan menyingkirkan produk-produk inflamasi yang menimbulkan nyeri (Yuspina, 2018). Terapi kompres hangat juga akan menyalurkan sinyal ke hypothalamus melalui spinal cord. Dengan adanya stimulasi reseptor yang panas dihipotalamus, efektor mengeluarkan signal yang menyebabkan pembuluh darah perifer melebar (Wulandari, 2016). Melebarnya pembuluh darah, maka akan memperlancar sirkulasi darah dan oksigenisasi ke bagian tubuh yang diberikan kompres hangat dan mengilangkan nyeri lokal.

Hasil penelitian menunjukkan terjadi penurunan nyeri punggung bawah ibu hamil trimester III yang signifikan sebelum dan sesudah dilakukan teknik akupressure. Penelitian ini sejalan dengan penelitian yang dilakukan oleh Permatasari (2019) di Puskesmas Jelakombo Jombang pada 22 ibu hamil trimester III yang diberikan intervensi akupressure, menunjukkan bahwa ada pengaruh akupressure terhadap penurunan nyeri punggung bawah ibu hamil trimester III. Penelitian serupa yang dilakukan oleh Sukeksi (2018) mengatakan bahwa terdapat pengaruh yang signifikan akupresur terhadap nyeri punggung ibu hamil di wilayah kerja Puskesmas Jogonalan I Klaten.

Akupresur berasal dari kata accus (jarum) dan pressure (menekan). Akupresur merupakan terapi yang dilakukan dengan memberikan stimulasi atau pijatan pada titik-titik tertentu atau acupoint pada tubuh. Stimulasi pada titik acupoint tubuh mempengaruhi aliran bioenergi tubuh (qi) menjadi teratur sehingga mengembalikan system keseimbangan tubuh (Setyowati, 2018). Penekanan pada titik acupoint, akan 
menstimulasi kelenjar pitutairy untuk melepaskan hormone oksitosin dan endorphin (Anggriawan, 2013). Kedua hormon tersebut bekerja bersama untuk menghilangkan rasa nyeri dengan meningkatkan aliran darah dan menghalangi sinyal rasa sakit yang dikirim ke otak (Therapy Directory, 2020).

Penekanan pada titik acupoint diketahui dapat merangsang serat Ad yang masuk ke bagian dorsalis medula spinalis. Hal ini menimbulkan inhibisi segmental dari rangsangan nyeri yang dihantarkan oleh serat $\mathrm{C}$ yang berjalan lebih lambat, dan melalui koneksi di otak bagian tengah, menyebabkan inhibisi rangsangan nyeri pada serat $\mathrm{C}$ di bagian lain dari medula spinalis. Hal ini dapat menerangkan mengapa pijatan akupresur pada titik tertentu dapat menghilangkan sensasi nyeri di bagian lain dari tubuh (Anita, 2018).

Berdasarkan hasil penelitian dapat diketahui bahwa tingkat nyeri punggung setelah diberikan terapi kompres hangat memiliki skala nyeri rata-rata 2,266 sedangkan pada kelompok yang sudah diberikan terapi akupressure memiliki skala nyeri ratarata lebih rendah yaitu 1,200. Selisih skala nyeri sesudah diberikan terapi kompres hangat dan terapi akupresur sebesar 1.066.Berdasarkan hasil dari uji Independent $t$ test didapatkan nilai $\mathrm{p}=0.001$ yang berarti <0.05. Hal ini menunjukkan bahwa ada perbedaan yang signifikan antara pemberian kompres hangat dan akupressure terhadap penurunan nyeri punggung bawah pada 30 responden ibu hamil trimester III di wilayah kerja Puskesmas Ngemplak.

Berdasarkan penelitian kedua teknik efektif menurunkan nyeri punggung, namun jika dilihat dari rata-rata penurunan nyeri pada kompres hangat yaitu 2,266 lebih besar dibanding dengan akupressure yaitu 1,200 yang berarti kompres hangat lebih signifikan dibandingkan akupressure untuk mengurangi nyeri punggung pada kehamilan trimester III. Kompres hangat maupun akupresur memiliki prisip yang sama dalam menurunkan nyeri punggung bawah ibu hamil trimester III dengan upaya penutupan gerbang nyeri (Gate Control Theory). Keduanya bekerja meningkatkan jumlah hormon endorfrin untuk merangsang serat Ad melalui medula spinalis yang menyebabkan rangsang nyeri dari serat $\mathrm{C}$ menjadi lebih lambat (Setyowati, 2018). Namun kompres hangat lebih signifikan dalam menurunkan nyeri karena menyebabkan peningkatkan sirkulasi dan oksigenasi yang langsung terjadi pada titik nyeri.

Kompres hangat pada dilakukan selama 20 menit pada punggung bawah ibu. Untuk menjaga stabilitas suhu saat melakukan intervensi ini, handuk harus dicelupkan pada air hangat secara berulang setiap 4 menit. Kompres hangat akan memberikan efek vasodilatasi pada pembuluh darah seingga akan memperlancar sirkulasi darah dan oksigenisasi ke bagian tubuh yang diberikan kompres hangat. Peningkatan sirkulasi darah akan meredakan penyebab nyeri lokal dengan menyingkirkan produk-produk inflamasi, seperti bradikin, histamin, dan prostaglandin (Zahroh \& Faiza, 2018).

Intervensi akupresure dilakukan selama 3 menit pada 4 titik yaitu titik BL23, GV3, GV4 dan KI3 sehingga total waktu dilakukan akupresur yaitu selama 12 menit. Penekanan dianggap stabil selama 3 menit pada masing-masing titik 
bila sepertiga kuku terapis menjadi putih saat menekan. Stimulasi pada acupoint tubuh mempengaruhi aliran bioenergi tubuh (qi) menjadi teratur sehingga mengembalikan system keseimbangan tubuh (Setyowati, 2018). Akupresur merupakan terapi yang mengirimkan sinyal ke tubuh untuk meningkatkan kesehatan dan kesejahteraan tubuh. Impuls nyeri dihantarkan ketika sebuah pertahanan dibuka dan impuls dihambat saat sebuah pertahanan tertutup.

\section{KESIMPULAN DAN SARAN}

Ada perbedaan signifikan nyeri punggung bawah responden sebelum dan sesudah diberikan intervensi kompres hangat $(\mathrm{p}=0.000)$. Nilai mean sebelum diberi intervensi kompres hangat 4,5 menjadi 2,2 dengan selisih mean 2,3. Ada perbedaan signifikan nyeri punggung bawah responden sebelum dan sesudah diberi intervensi akupressur $(\mathrm{p}=0.000)$. Nilai mean sebelum diberi intervensi akupressure 3,5 menjadi 2,3 dengan selisih mean 1,2 . Terdapat perbedaan yang bermakna dan signifikan untuk nyeri punggung bawah responden antara intervensi kompres hangat dan akupresur $(\mathrm{p}=0.001)$. Dengan kompres hangat lebih signifikan dalam menurunkan nyeri punggung bawah karena memiliki nilai mean 2,2 yang lebih besar dari nilai mean akupressur yaitu 1,6.

Saran yang diberikan sesuai dengan hasil penelitian ini adalah, kompres hangat dan akupresur dapat dilakukan di semua fasilitas pelayanan kesehatan, sehingga terapi ini dapat dijadikan program dalam kelas ibu. Bagi ibu hamil, dapat dijadikan alternaltif terapi nyeri punggung pada kehamilan trimester III dengan memberikan intervensi kompres hangat dan akupressure. Bagi peneliti selanjutnya, agar menambahkan jumlah subyek penelitian sesuai dengan perhitungan kebutuhan subyek penelitian dan menggunakan teknik acak sederhana dengan lotre dalam pengambilan sampel. Dapat mempertimbangkan waktu pemberian intervensi, dan menambahkan variable yaitu kombinasi antara kompres hangat dan akupresur.

\section{DAFTAR RUJUKAN}

Andreine, R. (2016). Analisis efektivitas kompres hangat terhadap penurunan nyeri persalinan. Rakernas Aipkema "Temu Ilmiah Hasil Penelitian Dan Pengabdian Masyarakat," 311-317.

Anggriawan, F. (2013). Tingkat keberhasilan masase Frirage dan Akupresure dalam Mengurangi Nyeri dan Meningkatkan ROM pada Pasien Cedera Bahu di Klinik Sasana Husada Yogyakarta. Yogyakarta. Universitas Negeri Yogyakarta.

Anita. (2018). Pengaruh Akupresur Lo4 ( he kuk ) dan Thai Cong terhadap Tingkat Nyeri Persalinan Kala I pada Ibu Bersalin. Jurnal Kesehatan, 9(November), 471-477.

Katonis, P., Kampouroglou, A., \& Alpantaki, K. (2011). Pregnancyrelated low back pain. Hippokratia, 15, 205-210.

Maryani, T. (2018). Pengaruh Kompres Hangat terhadap Intensitas Nyeri Punggung pada Ibu Hamil Trimester III di Klinik Pelita Hati Banguntapan Bantul. Universitas 'Aisyiyah Yogyakarta.

Movahedi, M., Ghafari, S., \& Valiani, M. 
(2017). The Effects of Acupressure on Pain Severity in Female Nurses with Chronic Low Back Pain Abstract Background: Materials and Methods : Results : Conclusions : Iranian Jornal of Nursing and Midwifery Research, 22(5), 339-342.

Notoatmojo, S. (2012). Metodologi Penelitian Kesehatan (2nd ed.). Jakarta: PT Rineka Cipta.

Permatasari, R. D. (2019). Efektifitas Tehnik Akupresur Pada Titik BL23 , GV 3 , GV 4 terhadap Penurunan Nyeri Punggung Bawah Pada Kehamilan Trimester III di Puskesmas Jelakombo Jombang. Jurnal Ilmiah, 2(1), 33-42.

Prabowo, E. (2012). Manfaat Kinesiotaping untuk Mengurangi Nyeri Punggung Bawah pada Kehamilan Trimester III. Jurnal Kesehatan, 5, 119-129.

Purnamasari, K. D. (2019). Nyeri Punggung Bawah Pada Ibu Hamil Trimester II Dan III. Midwifery Journal of Galuh University, 1, 9-15.

Rasyid, P. S., \& Igirisa, Y. (2019). The Effect Birthball Training on Back Pain in Third Semester Pregnant Woman in Kabila Community Health Center. Health Nations, 3(4), 173177.

Setyowati, H. (2018). Akupressure untuk kesehatan wanita (1st ed.). Magelang: Unimma Press.

Sukeksi, N. T., Kostania, G., \& Suryani,
E. (2018). Pengaruh Teknik Akupressure terhadap Nyeri Punggung Pada Ibu Hamil di Wilayah Puskesmas Jogonalan I Klaten. Jurnal Kebidanan Dan Kesehatan Tradisional, 3(1), 1-7.

Therapy Directory. (2020). Acupressure Treatment. Retrieved February 5, 2020, from https://www.therapydirectory.org.uk/articles/acupressure. html

Ummah, F. (2017). Nyeri Punggung pada Ibu Hamil ditinjau dari Body Mekanik dan Paritas di Desa Ketanen Kecamatan Panceng, Gresik, 03(Xiii).

Wulandari, P., Kustriyani, M., \& Chasanah, U. (2016). Pengaruh Pemberian Kompres Hangat terhadap Intensitas Nyeri pada Ibu Bersalin Kala I Fase Aktif di RB. Mardi, 393400.

Yuspina, A., Mulyani, N., \& Silalahi, U. A. (2018). Pengaruh Kompres Hangat dan Kompres Dingin terhadap Nyeri Tulang Belakang Ibu Hamil Trimester III di Wilayah Kerja Puskesmas Rajapolah tahun 2018. Jurnal Sehat Masada, 7(2).

Zahroh, C., \& Faiza, K. (2018). Pengaruh Kompres Hangat Terhadap Penurunan Nyeri Pada Penderita Penyakit Artritis Gout. Jurnal Ners Dan Kebidanan, 182-187. Retrieved from http://jnk.phb.ac.id/index.php/jnk\%0 APengaruh 